Arch. histol. jap. Vol. 26. n. 2 (December 1965). P. 187-202.

IInd Dept. of Anat. (Head: Prof. K. FUJIE) and Dept. of Surgery, IInd Clinic

(Head : Prof. Y. NAKAO), Wakayama Med. College, Wakayama.

\title{
Experimental Study on the Secretory Activity of the Gastric Chief Cells in the Operated Stomach.
}

胃切除が残胃胃腺主細胞の分泌機能に及ぼす影響に関する実験的研究.

$$
\text { Nobuji KONO 河野暢之. }
$$

(Received October 25, 1965.)

The subtotal resection of the stomach has attained wide use as surgical therapeutics in the case of the gastric and duodenal ulcer. In recent times, the advance and the improvement of operation method, narcosis, transfusion and antibiotics etc. combine to give greater success in this type of operation. However, though recidivation of the ulcer is arrested, it cannot be said that there are no undesirable effects for the individual in an operation which entails resection of the greater part of the stomach. This is because the stomach itself plays such an important role in the digesting and preservation of food, in secreting gastric juice, in making chymus etc. Therefore the technique of operating, which, while arresting recidivation of the ulcer preserves the stomach as much as possible together with its digestive activity is greatly to be desired.

The first to introduce vagotomy in the therapy of the peptic ulcer, for this purpose, were DRAGSTEDT and OWENS (1943). This method, however, has not been adopted because of the fact that the vagotomy alone brings about a gastric stasis, a lesser inhibition of acid secretion and a lesser degree of ulcer recidivity. As a result of progressive investigation on the gastric secretion and the etiology of the ulcer, the operation combining the gastric resection and the vagotomy was employed in a new attempt. SMITHWICK used hemigastrectomy with vagotomy and EDWARDS antrectomy with vagotomy, BEATTIE tested pylorectomy with vagotomy, SMITH and FARRIS employed pyloroplasty with vagotomy. These operations have attracted notice as a conservative gastrectomy and, at present, hemigastrectomy with vagotomy is widely used. These aim at a lesser secretion of acid and the preservation of the greater part of the stomach following the resection; $N$. vagus is cut so as to eliminate the cephalic phase of the gastric secretion and the half of the stomach containing the antrum is resected so as to reduce the gastric phase of the secretion.

The clinical reports on the results of hemigastrectomy with vagotomy state that the acidity of the gastric juice in the remaining stomach is reduced and that the effective arrest on the recidivity of the peptic ulcer can be obtained: However no report on the secretion of pepsin in the operated stomach can be found. Here, the author attempted to study the peptic secretion in the operated stomach on the gastric chief cells of dogs, from the point of view of the functional morphology, comparing the cases of the subtotal gastric resection and hemigastrectomy with vagotomy. 


\section{Materials and Methods.}

Experimental animals were adult dogs weighted $7-15 \mathrm{~kg}$ which were fed with food the content of which were kept as constant as possible. Ca. 150 dogs were divided into 5 groups and operated on as follows :

A-group: The subtotal gastrectomy of BILLROTH I type (the subtotal gastric resection and the gastroduodenostomy) (Fig. 1).

B-group: The subtotal gastrectomy of BILLROTH II type (the subtotal gastric resection and the gastrojejunostomy) (Fig. 1).

C-group: Vagotomy (subdiaphragmatic) and hemigastrectomy of BILLROTH I type (Fig. 2).

D-group: Vagotomy and hemigastrectomy of BILLROTH II type (Fig. 2).

E-group : Normal (contrast) dogs. Not operated.

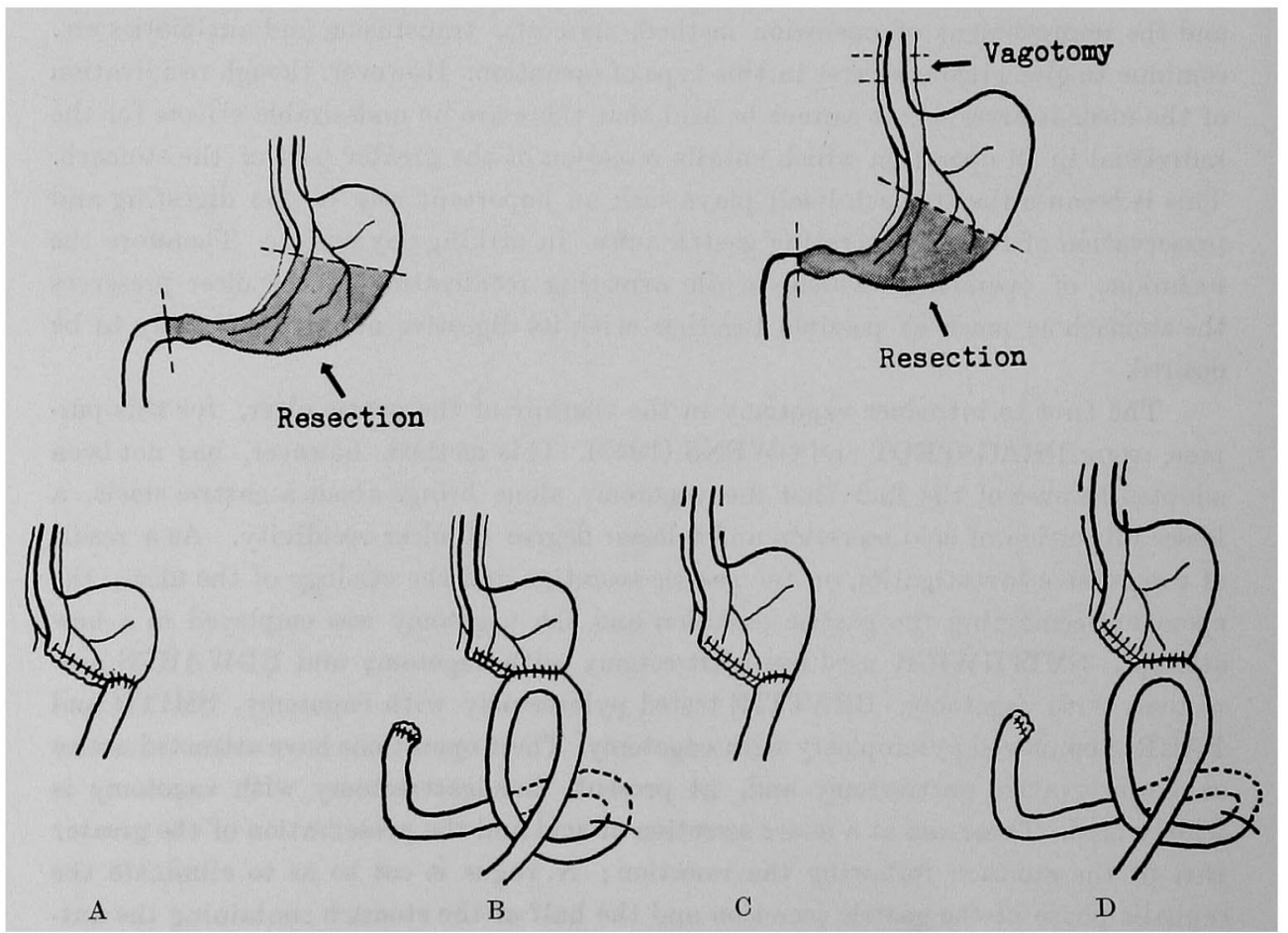

Fig. 1. Diagram of the subtotal gastrectomy (A and $\mathrm{B}$ groups).

Fig. 2. Diagram of hemigastrectomy with vagotomy (C and $\mathrm{D}$ groups). In this case, the border between the resected and the remaining stomach is the line tying the third branch of $\mathrm{A}$. gast. sinist. and the joining of A. gastroepip. sinist. with A. gastroepip. dext.

For the operation, dogs were injected with thiopental sodium (Ravonal) $25 \mathrm{mg} / \mathrm{kg}$ for the narcosis, then the abdomen was opened with the upper median incision. After the operation penicillin 200,000 units was injected into the abdominal cavity.

Each group of A-D was divided into 4 small groups according to the post-opera- 
tive term, i. e, 1 week, 2 weeks, 1 month and 3 months. Materials were taken at periods of 1 . before administration of the diet (unfed for $24 \mathrm{hrs}$ ) and 2. $\frac{1}{2}, 1,2$, 3 hrs. after the diet.

To take materials, under deep narcosis by the intravenous injection of thiopental sodium, the thorax and the abdomen were opened. LUNA's liquid ( $250 \mathrm{ml}$ ) was injected into the left heart ventricle with a constant pressure for the vital fixation, the small pieces of the stomach were taken out and they were placed in KOLSTER's liquid for the post fixation. The hydration of the materials and the embedding in paraffin was done in the conventional way. Paraffin sections were cut at $4 \mu$ and stained by HEIDENHAIN's iron haematoxylin.

\section{Observations.}

The chief cells of the gastric glands and the surface epithelial cells of the gastric mucosa were observed. The reason why the author observed the surface epithelial cells is that the surface cells contain the productin vacuoles of FUJIE the contents of which promote the production of secretory granules in the gastric chief cells and consequently the quantity of the productin vacuoles in the surface cells can be of help to determining the secretory activity in the chief cells. The quantity of the productin vacuoles was marked,,++++++ etc. using the standard shown in Fig. 3.

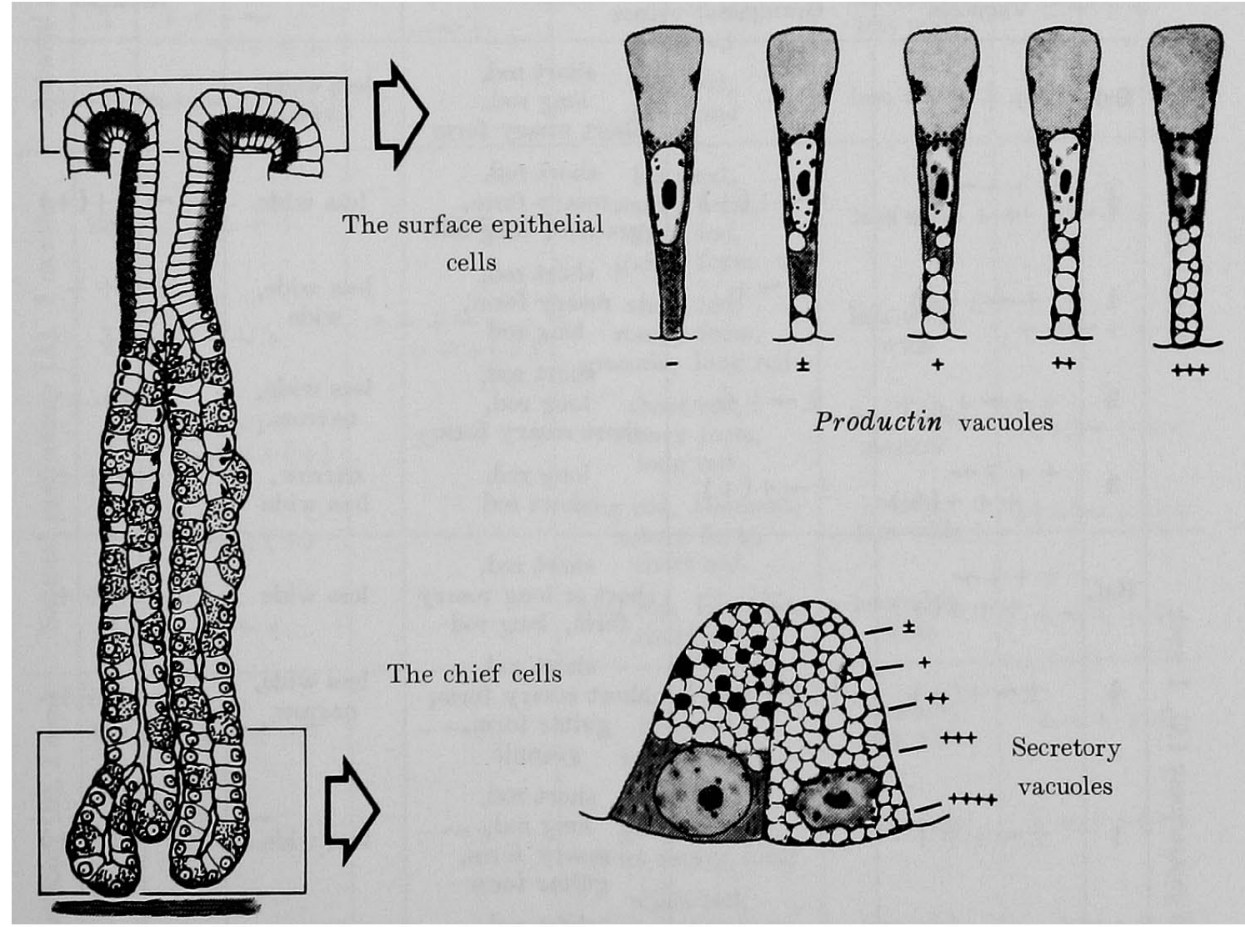

Fig. 3. Schematic diagrams showing the quantity of productin vacuoles in the gastric surface epithelial cells and of secretory vacuoles in the gastric chief cells. Secretory granules in the chief cells are mostly straggling among secretory vacuoles. Their quantity is determined by converting them into the quantitative standard of secretory vacuoles. 
As regards the gastric chief cells, the quantity of secretory granules and secretory vacuoles in the cells, the form of mitochondria are described. In addition to that, the aspect of the gland lumen (wide, less wide, narrow) is noted, and the secretory activity of the chief cells collectively is interpreted.

In most cases, the gastric chief cells contain so much secretory vacuoles that the author first determined the standard of their quantity: When the vacuoles occupy the cell body, it was marked ++++ . If no vacuoles were seen in the cell, it was marked - , and the intermediate stages of,,,++++++ \pm were used between ++++ and - (Fig. 3). When secretcry granules are seen in the cell, they are mostly straggling among secretory vacuoles; the author marked them by converting them into the quantitative standard of secretory vacuoles.

The results obtained are summarized in Table 1 and Table 2.

Table 1. The results obtained from the gastric chief cells and the surface epithelial cells. (Bef. = before administration of food.)

\begin{tabular}{|c|c|c|c|c|c|c|}
\hline \multirow{3}{*}{$\operatorname{Exp}$} & \multirow{3}{*}{ Hrs. } & \multicolumn{3}{|c|}{ The gastric chief cells } & \multirow{3}{*}{$\begin{array}{l}\text { Gland } \\
\text { lumen }\end{array}$} & \multirow{3}{*}{$\begin{array}{c}\begin{array}{c}\text { The surface } \\
\text { epithelial cells }\end{array} \\
\begin{array}{c}\text { Productin } \\
\text { vacuoles }\end{array}\end{array}$} \\
\hline & & \multicolumn{2}{|c|}{$\begin{array}{l}\text { Quantity of the intracellular } \\
\text { secretory substance }\end{array}$} & \multirow{2}{*}{$\begin{array}{c}\text { Form of } \\
\text { mitochodria }\end{array}$} & & \\
\hline & & Vacuoles & Granules & & & \\
\hline \multirow{5}{*}{ 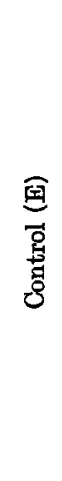 } & Bef. & ++++ & - & $\begin{array}{c}\text { short rod, } \\
\text { long rod, } \\
\text { short rosary form }\end{array}$ & $\begin{array}{l}\text { less wide, } \\
\text { (wide) }\end{array}$ & $+\sim++t$ \\
\hline & $\frac{1}{2}$ & $\begin{array}{l}+++\sim \\
+++(+)\end{array}$ & $\pm \sim+(+)$ & $\begin{array}{l}\text { short rod, } \\
\text { rosary form, } \\
\text { granule, long rod }\end{array}$ & less wide & $+\sim++(+)$ \\
\hline & 1 & $+\sim+(+)$ & $\pm \sim+$ & $\begin{array}{l}\text { short rod, } \\
\text { rosary form, } \\
\text { long rod }\end{array}$ & $\begin{array}{l}\text { less wide, } \\
\text { wide }\end{array}$ & $\pm \sim++$ \\
\hline & 2 & $++\sim+++$ & $\pm \sim++$ & $\begin{array}{c}\text { short rod, } \\
\text { long rod, } \\
\text { short rosary form }\end{array}$ & $\begin{array}{l}\text { less wide, } \\
\text { na rrow }\end{array}$ & $\pm \sim++$ \\
\hline & 3 & $\begin{array}{l}+++\sim \\
+++(+)\end{array}$ & $\pm \sim+(+)$ & $\begin{array}{l}\text { long rod, } \\
\text { short rod }\end{array}$ & $\begin{array}{l}\text { narrow, } \\
\text { less wide }\end{array}$ & $+\sim+++$ \\
\hline \multirow{5}{*}{ 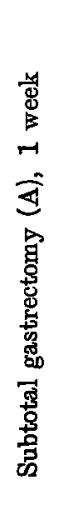 } & Bef. & $\begin{array}{l}+++\sim \\
+++(+)\end{array}$ & - & $\begin{array}{l}\text { short rod, } \\
\text { short or long rosary } \\
\text { form, long rod }\end{array}$ & less wide & $+\sim+++$ \\
\hline & $\frac{1}{2}$ & $\pm \sim+(+)$ & $+(+) \sim+++$ & $\begin{array}{l}\text { short rod, } \\
\text { short rosary form, } \\
\text { guitar form, } \\
\text { granule }\end{array}$ & $\begin{array}{l}\text { less wide, } \\
\text { narrow }\end{array}$ & $+\sim+++$ \\
\hline & 1 & $\pm \sim+++$ & - & $\begin{array}{l}\text { short rod, } \\
\text { long rod, } \\
\text { rosary form, } \\
\text { guitar form }\end{array}$ & less wide & $+\sim++(+)$ \\
\hline & 2 & $+(+) \sim+++$ & $-\sim \pm$ & $\begin{array}{l}\text { short rod, } \\
\text { short rosary form, } \\
\text { rosary form }\end{array}$ & naxrow & $-\sim++$ \\
\hline & 3 & $\begin{array}{l}++\underset{++}{+} \\
++\end{array}$ & $\pm \sim++$ & $\begin{array}{l}\text { long rod, short } \\
\text { rod, rosary form }\end{array}$ & $\begin{array}{l}\text { less wide, } \\
\text { narrow }\end{array}$ & $+\sim+++$ \\
\hline
\end{tabular}




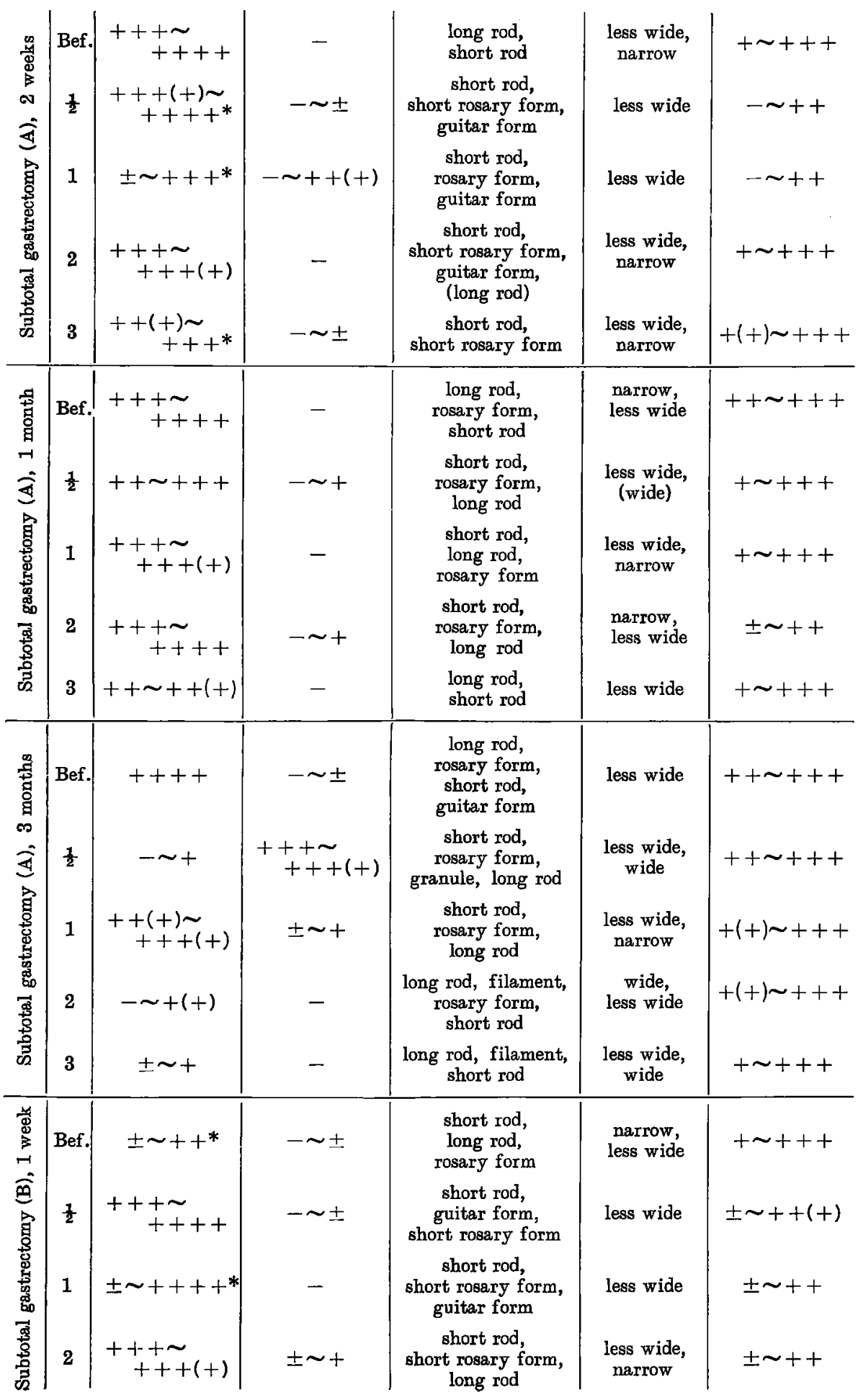




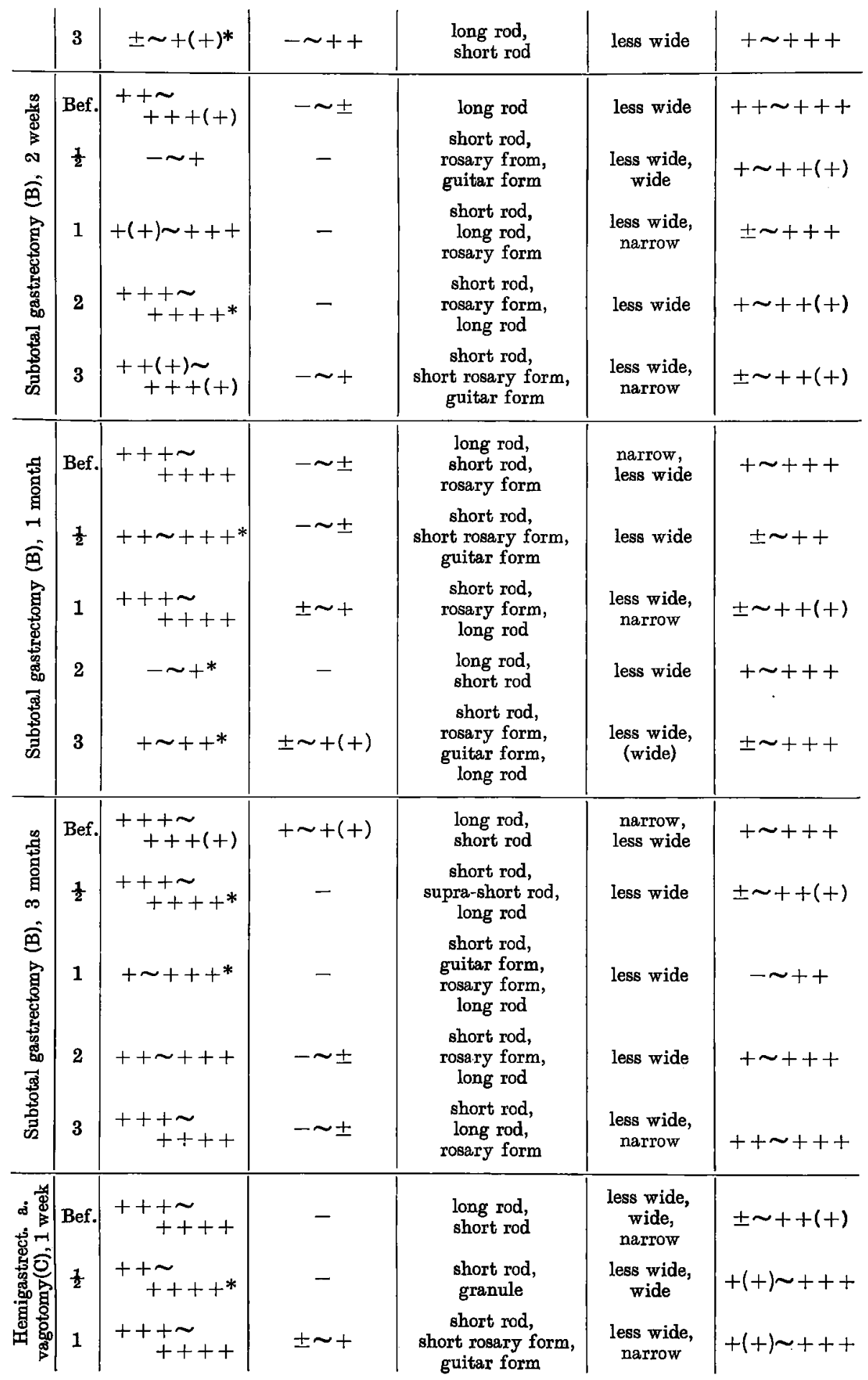




\begin{tabular}{|c|c|c|c|c|c|c|}
\hline & 3 & $\begin{array}{l}\begin{array}{c}+(+) \sim \\
+++ \\
+(+) \sim+++\end{array} \\
\end{array}$ & $\sim \sim \pm$ & $\begin{array}{l}\text { short rod, } \\
\text { supra-short rod, } \\
\text { rosary form } \\
\text { short rod, } \\
\text { short rosary form, } \\
\text { long rod }\end{array}$ & $\begin{array}{l}\text { less wide, } \\
\text { narrow } \\
\text { narrow, } \\
\text { less wide }\end{array}$ & $\begin{array}{l}+\sim++(+) \\
++\sim+++\end{array}$ \\
\hline \multirow{5}{*}{ 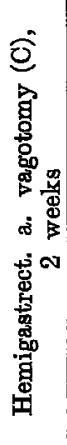 } & Bef. & $\begin{array}{l}+++\sim \\
++++^{*}\end{array}$ & - & $\begin{array}{l}\text { long rod, } \\
\text { short rod }\end{array}$ & less wide & $+\sim+++$ \\
\hline & $\frac{1}{2}$ & $\begin{array}{r}++(+) \sim \\
+++\end{array}$ & - & $\begin{array}{l}\text { short rod, } \\
\text { long rod, } \\
\text { rosary form }\end{array}$ & less wide & $+\sim+++$ \\
\hline & 1 & $\begin{aligned} &+++\sim \\
&++++\end{aligned}$ & 一 & $\begin{array}{l}\text { short rod, } \\
\text { rosary form, }\end{array}$ & less wide & $+\sim++(+)$ \\
\hline & 2 & $\begin{array}{l}+++\sim \\
+++(+)\end{array}$ & $-\sim \pm$ & $\begin{array}{l}\text { short rod, } \\
\text { guitar form, } \\
\text { short rosary form }\end{array}$ & $\begin{array}{c}\text { less wide, } \\
\text { wide, } \\
\text { (narrow) }\end{array}$ & $+(+) \sim+++$ \\
\hline & 3 & $\begin{array}{l}+++\underset{++}{+} \\
+++\end{array}$ & $\pm \sim+(+)$ & $\begin{array}{l}\text { long rod, } \\
\text { short rod }\end{array}$ & $\begin{array}{l}\text { less wide, } \\
\text { narrow }\end{array}$ & $+\sim+++$ \\
\hline \multirow{5}{*}{ 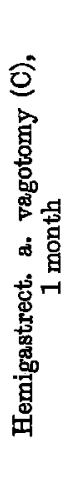 } & Bef. & $\begin{aligned} &+++\sim \\
&++++\end{aligned}$ & - & $\begin{array}{l}\text { short rod, } \\
\text { short rosary form, } \\
\text { supra-short rod }\end{array}$ & $\begin{array}{l}\text { narrow, } \\
\text { less wide }\end{array}$ & $+\sim++$ \\
\hline & $\frac{-1}{2}$ & $++\sim+++$ & $\begin{array}{l}+(+) \sim \\
++(+)\end{array}$ & $\begin{array}{l}\text { short rod, } \\
\text { long rod, } \\
\text { rosary form }\end{array}$ & less wide & $\pm \sim+++$ \\
\hline & 1 & $\begin{array}{l}+++\underset{++}{+} \\
++\end{array}$ & $-\sim+$ & $\begin{array}{l}\text { supra-short rod, } \\
\text { guitar form, } \\
\text { short rod }\end{array}$ & $\begin{array}{c}\text { less wide, } \\
\text { narrow }\end{array}$ & $+\sim+++$ \\
\hline & 2 & ++++ & - & $\begin{array}{l}\text { granule, } \\
\text { guitar form, } \\
\text { short rod }\end{array}$ & $\begin{array}{l}\text { narrow, } \\
\text { less wide }\end{array}$ & $+\sim++(+)$ \\
\hline & 3 & $\begin{aligned}++ & \sim \\
& \sim+++\end{aligned}$ & - & $\begin{array}{l}\text { short rod, } \\
\text { long rod, } \\
\text { guitar form }\end{array}$ & less wide & $+\sim+++$ \\
\hline \multirow{5}{*}{ 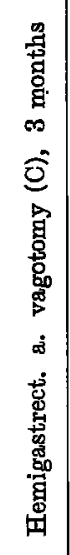 } & Bef. & $+t+t$ & 一 & $\begin{array}{l}\text { granule, } \\
\text { short rosary form, } \\
\text { short rod }\end{array}$ & less wide & $+\sim+++$ \\
\hline & $\frac{1}{2}$ & $+\underset{+}{+}+t$ & $+\sim+++$ & $\begin{array}{l}\text { short rod, } \\
\text { short rosary form, } \\
\text { guitar form, } \\
\text { long rod }\end{array}$ & $\begin{array}{l}\text { less wide, } \\
\text { narrow }\end{array}$ & $+(+) \sim+++$ \\
\hline & 1 & $+\sim+(+)$ & $\begin{array}{l}+++\sim \\
+++(+)\end{array}$ & $\begin{array}{l}\text { short rod, } \\
\text { rosary form, } \\
\text { long rod, } \\
\text { granule }\end{array}$ & $\begin{array}{l}\text { narrow, } \\
\text { less wide }\end{array}$ & $++\sim+++$ \\
\hline & 2 & $+\sim++$ & $\stackrel{+\underset{+}{+}++}{\sim}$ & $\begin{array}{l}\text { long rod, } \\
\text { short rod, } \\
\text { guitar form }\end{array}$ & narrow & $+\sim+++$ \\
\hline & 3 & $++\sim+++$ & - & $\begin{array}{l}\text { short rod, } \\
\text { long rod, } \\
\text { granule }\end{array}$ & $\begin{array}{l}\text { narrow, } \\
\text { less wide }\end{array}$ & $\pm \sim++(+)$ \\
\hline & Bef. & ++++ & $-\sim \pm$ & $\begin{array}{l}\text { short rosary form, } \\
\text { guitar form, } \\
\text { short rod }\end{array}$ & $\begin{array}{c}\text { less wide, } \\
\text { narrow }\end{array}$ & $+\sim+$ \\
\hline
\end{tabular}




\begin{tabular}{|c|c|c|c|c|c|c|}
\hline 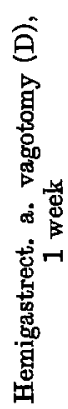 & $\frac{7}{2}$ & $\begin{array}{c}++++ \\
+\sim++^{*} \\
\pm \sim++(+)^{*}\end{array}$ & $\begin{array}{c}-\sim+ \\
++\sim+++ \\
-\sim \pm\end{array}$ & $\begin{array}{l}\text { short rod, } \\
\text { short rosary form, } \\
\text { guitar form } \\
\text { short rod, } \\
\text { rosary form, } \\
\text { long rod } \\
\text { short rod, } \\
\text { long rod, } \\
\text { rosary form } \\
\text { short rod, } \\
\text { long rod, } \\
\text { rosary form }\end{array}$ & $\begin{array}{c}\text { narrow, } \\
\text { less wide } \\
\text { less wide } \\
\text { less wide, } \\
\text { (wide) }\end{array}$ & $\begin{array}{l}-\sim++(+) \\
\pm \sim+++ \\
+\sim+++\end{array}$ \\
\hline 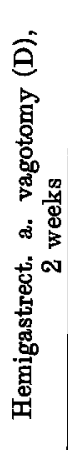 & $\begin{array}{l}\text { Bef. } \\
\frac{1}{2} \\
1 \\
2 \\
3\end{array}$ & 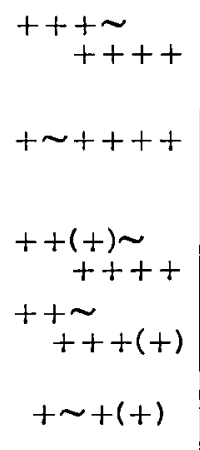 & $\begin{array}{c}t \sim++ \\
\pm \sim++(+) \\
t \sim+(+)\end{array}$ & $\begin{array}{l}\text { long rod, } \\
\text { short rod } \\
\text { short rod, } \\
\text { rosary form, } \\
\text { long rod, } \\
\text { guitar form } \\
\text { short rod. } \\
\text { short rosary form } \\
\text { short rod, } \\
\text { long rod } \\
\text { long rod, } \\
\text { short rod, } \\
\text { rosary form }\end{array}$ & $\begin{array}{l}\text { less wide, } \\
\text { wide } \\
\text { less wide, } \\
\text { narrow } \\
\text { less wide }\end{array}$ & $\begin{array}{l}+\sim+++ \\
\pm \sim+++ \\
+\sim+++ \\
+\sim+++\end{array}$ \\
\hline 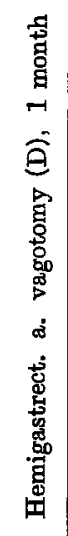 & Bef. & 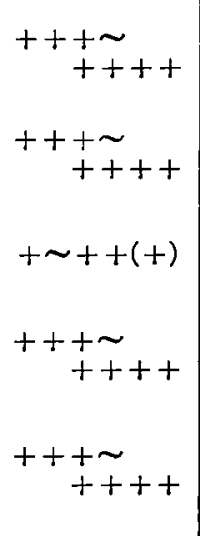 & $\begin{array}{l}-\sim \pm \\
-\sim \pm\end{array}$ & $\begin{array}{l}\text { short rod, } \\
\text { supra-short rod, } \\
\text { granule } \\
\text { short rod, } \\
\text { guitar form, } \\
\text { granule } \\
\text { short rod, } \\
\text { guitar form, } \\
\text { long rod } \\
\text { short rod, } \\
\text { short rosary form, } \\
\text { guitar form } \\
\text { short rod, } \\
\text { long rod, } \\
\text { guitar form, } \\
\text { rosary form }\end{array}$ & $\begin{array}{c}\text { narrow, } \\
\text { less wide } \\
\text { less wide, } \\
\text { narrow } \\
\text { less wide, } \\
\text { wide }\end{array}$ & $\begin{array}{l}t \sim+++ \\
t \sim++(+) \\
\pm \sim++(+) \\
t \sim++(+)\end{array}$ \\
\hline 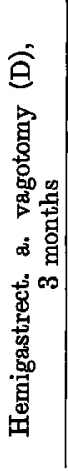 & Bef. & $\begin{array}{l}+\sim++ \\
+++(+) \sim \\
++++ \\
++\sim++ \\
+++\sim+t \\
++++ \\
+\sim++\end{array}$ & $\begin{array}{c}- \\
+\sim++(+) \\
\pm \sim++\end{array}$ & $\begin{array}{l}\text { Iong rod, } \\
\text { short rod, } \\
\text { short rod, } \\
\text { guitar form, } \\
\text { granule } \\
\text { long rod, } \\
\text { short rod } \\
\text { short rod, } \\
\text { rosary form, } \\
\text { long rod } \\
\text { short rod, } \\
\text { short rosary form, } \\
\text { guitar form, } \\
\text { rosary form }\end{array}$ & $\begin{array}{l}\text { narrow, } \\
\text { less wide, } \\
\text { less wide } \\
\text { less wide, } \\
\text { wide } \\
\text { less wide, } \\
\text { narrow } \\
\text { less wide, } \\
\text { (narrow) }\end{array}$ & $\begin{array}{l}+\sim+++ \\
+\sim+++ \\
+\sim+++ \\
\pm \sim++\end{array}$ \\
\hline
\end{tabular}


* In the group, an atrophy of the gastric wall, a hyperplasia of the connective tissue, an atrophy of the gland etc. were observed.

Table 2. The general condition of the operated dogs.

\begin{tabular}{|c|c|c|c|c|c|c|c|c|c|c|}
\hline \multirow{3}{*}{$\begin{array}{l}\text { 号 } \\
\text { 总 }\end{array}$} & & \multicolumn{3}{|c|}{ Emaciation } & \multicolumn{2}{|c|}{ Vomiting } & \multicolumn{3}{|c|}{ Appetite } & \multirow[b]{2}{*}{ Additional } \\
\hline & 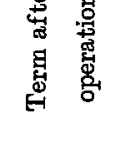 & 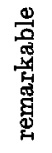 & 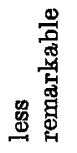 & 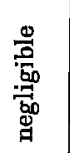 & 总 & 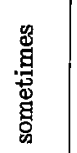 & 'ర్ర & 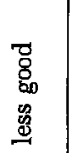 & 总 & \\
\hline & $\begin{array}{l}1 \text { week } \\
2 \text { weeks } \\
1 \text { month } \\
3 \text { months }\end{array}$ & $\begin{array}{l}40 \\
20\end{array}$ & $\begin{array}{l}20 \% \\
40 \\
50 \\
80\end{array}$ & $\begin{array}{l}80 \% \\
60 \\
10\end{array}$ & & $\begin{array}{l}20 \% \\
20 \\
80 \\
40\end{array}$ & $\begin{array}{l}40 \% \\
40 \\
60 \\
80\end{array}$ & $\begin{array}{l}20 \% \\
60 \\
40 \\
20\end{array}$ & $40 \%$ & $\begin{array}{lr}\text { Stenosis (?) } & 10 \% \\
\text { Adhesion } & 20 \% \\
\text { Gastric dilatation } & 20 \% \\
& 20 \%\end{array}$ \\
\hline B & $\begin{array}{l}1 \text { week } \\
2 \text { weeks } \\
1 \text { month } \\
3 \text { months }\end{array}$ & $\begin{array}{l}20 \\
10\end{array}$ & $\begin{array}{l}20 \\
40 \\
40 \\
40\end{array}$ & $\begin{array}{l}80 \\
40 \\
50 \\
60\end{array}$ & 10 & $\begin{array}{l}20 \\
40 \\
40\end{array}$ & $\begin{array}{l}40 \\
60 \\
80 \\
60\end{array}$ & $\begin{array}{l}40 \\
40 \\
20 \\
40\end{array}$ & 20 & $\begin{array}{lr}\text { Adhesion } & 20 \\
\text { Adhesion } & 20 \\
\text { Gastric dilatation } & 20\end{array}$ \\
\hline $\mathrm{C}$ & $\begin{array}{l}1 \text { week } \\
2 \text { weeks } \\
1 \text { month } \\
3 \text { months }\end{array}$ & & $\begin{array}{l}20 \\
40 \\
20\end{array}$ & $\begin{array}{l}80 \\
60 \\
80\end{array}$ & & $\begin{array}{l}40 \\
20 \\
20\end{array}$ & $\begin{array}{l}40 \\
40 \\
80\end{array}$ & $\begin{array}{l}40 \\
60 \\
20\end{array}$ & 40 & $\begin{array}{ll}\text { Gastric dilatation } & 40 \\
\text { Adhesicn } & 10 \\
\text { Bleeding of mucosa } & 10 \\
\text { Gastric dilatation } & 20 \\
\text { Gastric dilatation } & 40 \\
\text { Gastric dilatation } & 20\end{array}$ \\
\hline D & $\begin{array}{l}1 \text { week } \\
2 \text { weeks } \\
1 \text { month } \\
3 \text { months }\end{array}$ & 20 & $\begin{array}{l}10 \\
40 \\
20\end{array}$ & $\begin{array}{l}40 \\
80\end{array}$ & 20 & 20 & $\begin{array}{l}80 \\
20 \\
60\end{array}$ & $\begin{array}{l}60 \\
40\end{array}$ & 20 & $\begin{array}{lr}\text { Gastric dilatation } & 20 \\
\text { Gastritis } & 10 \\
\text { Adhesion } & 20 \\
\text { Gastric dilatation } & 40 \\
\text { Adhesion } & 20 \\
\text { Gastric dilatation } & 40\end{array}$ \\
\hline
\end{tabular}

\section{Discussion.}

In normal dog, the secretory granules produced in the chief cells liquefy quickly in the cells. (It appears as vacuolization). When the production of secretory substance in the cell is initiated, an increase of secretory granules and, at almost the same time, of secretory vacuoles can be observed; the form of mitochondria tends to the granulation, and short rod shaped, rosary formed as well as granule shaped mitochondria increase in the cell. When the discharge of secretory substance from the cell is initiated, a decrease of secretory vacuoles in the cell and, sometimes, a dilatation of the gland lumen are observable.

For the sake of convenience in discussing the observations, the quantities of secretory vacuoles and secretory granules in the chief cells and of productin vacuoles in 
the surface epithelial cells, which were described in Table 1, are shown again in diagrams (Fig. 4-20).

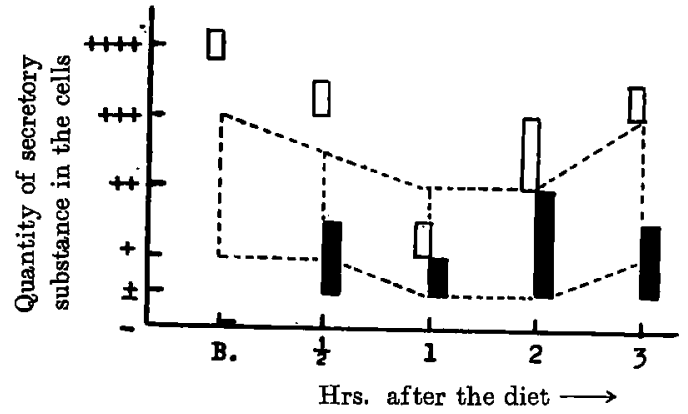

Fig. 4. The normal case. $B$ Before administration of the diet. $\square$ Secretory vacuoles and $\square$ secretory granules in the chief cells, $\ldots$ productin vacuoles in the surface epithelial cells.
In the control case (Fig. 4), secretory vacuoles are replete in the cell before administration of the diet (unfed for $24 \mathrm{hrs.}$ ). They seem to be ready for the discharge to follow. No active form of mitochondria can be seen. At the periods of $1 / 2$ hr. after the diet, both an increase of secretory granules and a decrease of secretory vacuoles can be seen in the cell. The increase of secretory granules indicates the activity of the production of the granules in the cell, and it is also

conformed by the active transformation of mitochondria. Therefore, secretory vacuoles must increase in the cell at the same time. In fact, however, they are fewer than in the case of the unfed group. These observations may be explicable by the fact that the activity of discharge exceeds the activity of production. It is more obvious at periods of $1 \mathrm{hr}$. after the diet. In 2 and $3 \mathrm{hrs}$. after the diet, a gradual lowering on the activity of the production of secretory granules can be presumed from the form of mitochondria, but an increase of secretory granules and vacuoles in the cell is observed. This fact suggests that the secretory granules produced are accumulated and vacuolized in the cell without being discharged from the cell. Productin vacuoles in the gastric surface epithelial cells decrease after the diet then gradually increase again in the cell ; the fluctuation coincides precisely with the activity of the production of secretory granules in the chief cells.

In the cases of the subtotal gastric resection and the gastroduodenostomy (A-group, Fig. 5-8), it is noticed, first of all, that the functional movements of the chief cells after the diet differ from those of the normal case. According to the quantity of secretory vacuoles in the chief cells, the peak of the discharge of secretory substance can be presumed to be $1 / 2 \mathrm{hr}$. after the diet in the period of one week after the operation (Fig. 5), at 1 and $3 \mathrm{hrs}$. after the diet in the two-week period (Fig. 6), at $1 / 2$ and $3 \mathrm{hrs}$. in the one-month period (Fig. 7), at $1 / 2$ and $2 \mathrm{hrs}$. in the three-month period after the operation (Fig. 8). The two peaks of the discharge after the diet become the more obvious, the longer the term after the operation. The production of secretory granules in the chief cells after the diet does not progress as in the normal case, and irregular activity can be seen. These irregularities coincide with the discharge of productin vacuoles from the surface epithelial cells. The observations seem to indicate an unbalance in the action between sympathetic and parasympathetic nerves owing to the resection of the most part of the stomach. In cases of $1 / 2 \mathrm{hr}$. after diet during the one-week and three-month post-operation periods, and $1 \mathrm{hr}$. after diet during the twoweek period, an abnormally large quantity of secretory granules and a remarkable granulation of mitochondria in the chief cells can be observed, while no discharge of 


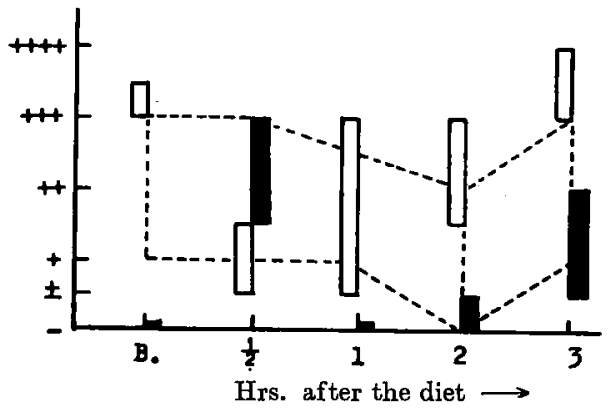

Fig. 5. 1 week after the subtotal gastrectomy of B-I type (A-group).

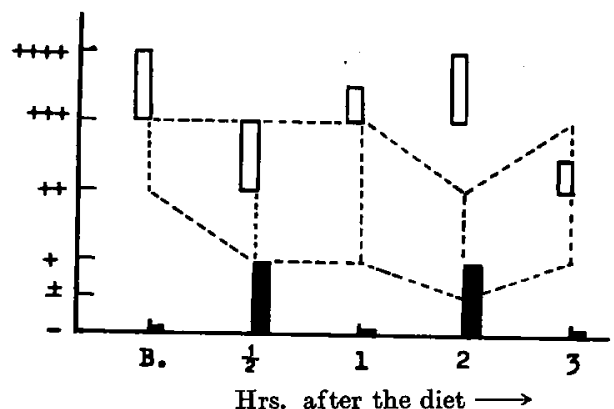

Fig. 7. 1 month after the subtotal gastrectomy of B-I type (A-group).

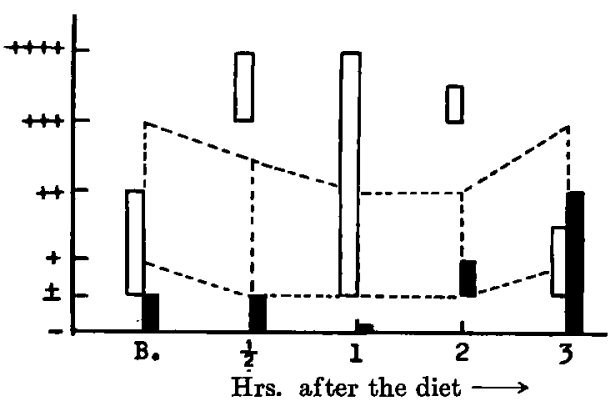

Fig. 9. 1 week after the subtotal gastrectomy of B-II type (B-group).

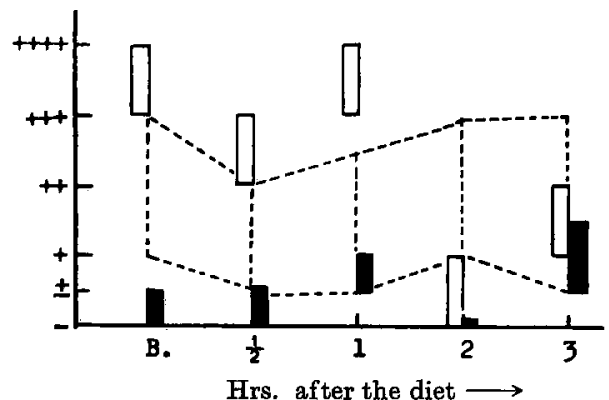

Fig. 11. 1 month after the subtotal gastrectomy of B-II type (B-group).

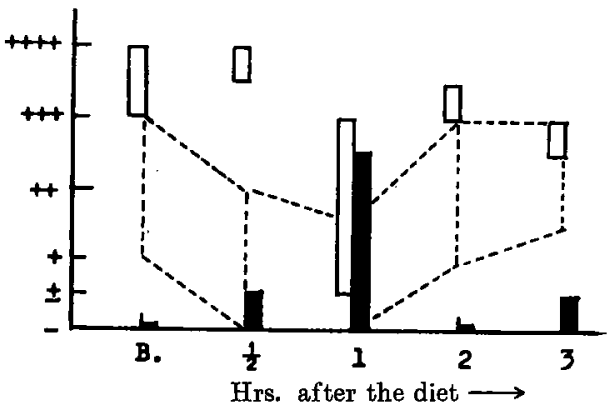

Fig. 6. 2 weeks after the subtotal gastrectomy of B-I type (A-group).

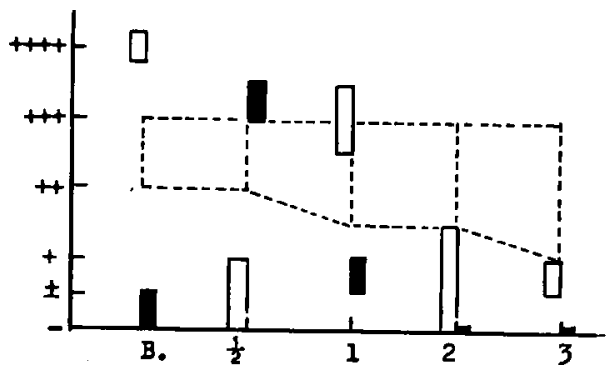

Hrs. after the diet $\longrightarrow$

Fig. 8. 3 months after the subtotal gastrectomy of B-I type (A-group).

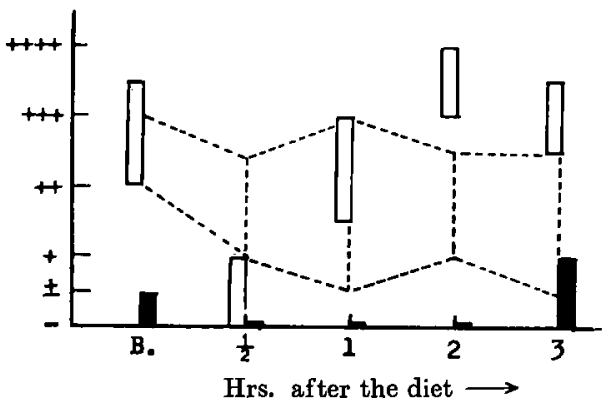

Fig. 10. 2 weeks after the subtotal gastrectomy of B-II type (B-group).

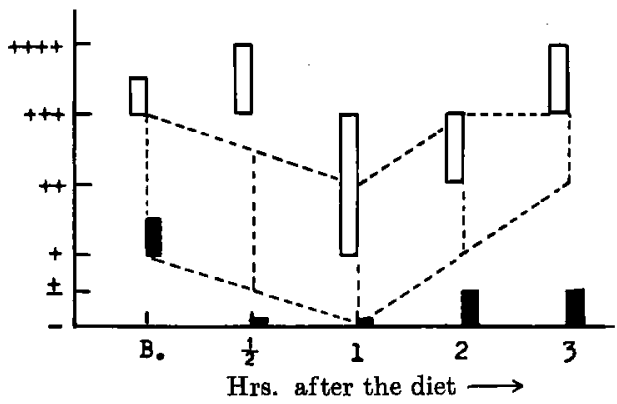

Fig. 12. 3 months after the subtotal gastrectomy of B-II type (B-group). 
the productin vacuoles from the surface epithelial cells is seen. According to the findings of AMANO (1947), the electric stimulation of b-sympathetic zone in the brain of cats induces a remarkable production of secretory substance in the gastric chief cells. Considering the author's findings basing on the innervation in the gland cells, we come to the conclusion that it results from the unilateral action of the sympathetic nerve. In spite of the irregular activity of the secretion and the abnormal figures of the cell, the secretory activity of the individual chief cell in A-group is, on the whole, within the physiological limit.

In the cases of the subtotal gastrectomy of B-II type (B-group, Fig. 9-12), the fluctuation of productin vacuoles in the surface epithelial cells seems to be similar to that of the normal case. The production of secretory substance in the chief cells is initiated without any abnormal characteristics. The discharge of secretory vacuoles from the chief cells seems to have two peaks in the one-week (Fig. 9), the two-week (Fig. 10) and the one-month (Fig. 11) groups, and only one peak in the three-month group (Fig. 12). This is a contrary relation to that obtained from A-group.

To sum up the results of $A$ and $B$ groups, it is noticed that the secretory activity of the individual chief cell is initiated within a physiological limit and that the activity of the chief cell after the diet is considerably irregular in A-group, which seem to be due to the unbalanced action of the autonomic nerves. As the difference of the operation between A-group and B-group is seen only in the gastroduodenostomy and the gastrojejunostomy, the differences of the observations may be explained by the different stagnation of food in the stomach.

The observations obtained from C-group (vagotomy and hemigastrectomy of B-I type, Fig. 13-16) and D-group (vagotomy and hemigastrectomy of B-II type, Fig. 17 -20) are not discussible as a continuous process of the secretory activity in the chief cells regarding to administration of food. There is observable an active production of secretory granules in the chief cells before administration of food, or no discharge of secretory vacuoles after the food, or an irregular fluctuation of productin vacuoles in the surface epithelial cells etc. These cannot be explained but as the irregular and unilateral actions of the sympathetic nerve or the non-action of the parasympathetic nerve resulting from the vagotomy. Even in these disorders of the cell activity, it is noticed from the observations of the individual cells that the discharge of secretory vacuoles from the chief cells and of product in vacuoles from the surface epithelial cells is not always inhibited after vagotomy and that the secretory activity of the chief cells tends toward the production of secretory granules. It is also noticed in $\mathrm{C}$ and $\mathrm{D}$ groups that the chief cells containing an abnormally large quantity of secretory granules are frequently observable. In these cases, the productin vacoules in the surface cells do not decrease and the transformation of mitochondria in the chief cells is not so remarkable as to presume it to be abnormal activity. Therefore, the observations seem to indicate that the production of secretory granules is active and the secretory granules produced are accumulated in the chief cell and that the liquefaction of the granules '(which appears as vacuolization, the begining" of the process of discharge) is prolonged or inhibited.

Observations similar to those above mentioned were rarely foünd in $\mathbf{A}$ and $\mathbf{B}$ groups. These observations, the author feels, are to be explained by the one-sided 


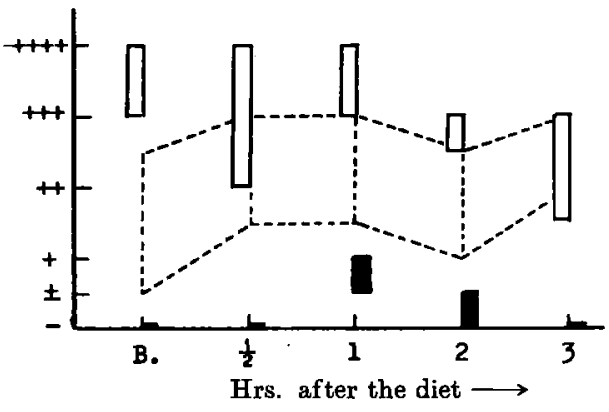

Fig. 13. 1 week after vagotomy and hemigastrectomy of B-I type (C-group).

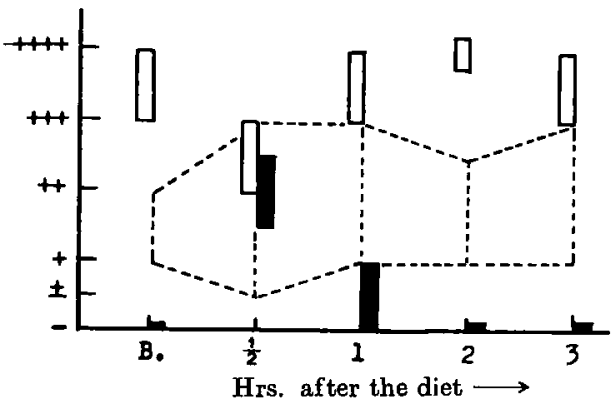

Fig. 15. 1 month after vagotomy and hemigastrectomy of B-I type (C-group).

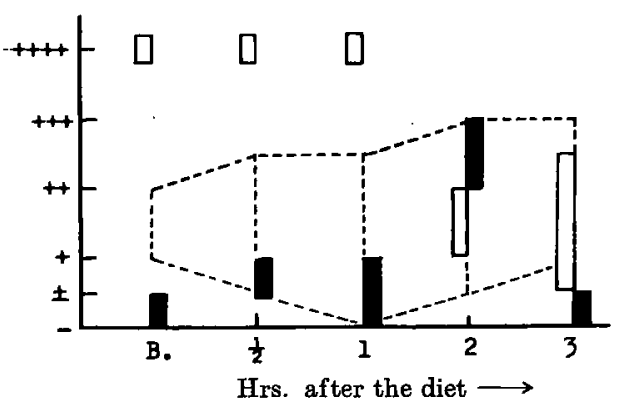

Fig. 17. 1 week after vagotomy and hemigastrectomy of B-II type (D-group).

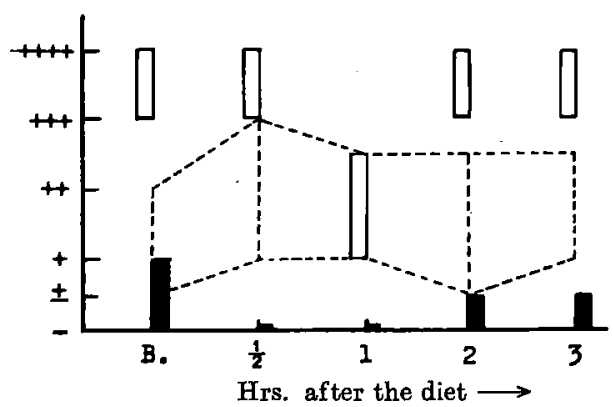

Fig. 19. 1 month after vagotomy and hemigastrectomy of B-II type (D-group).

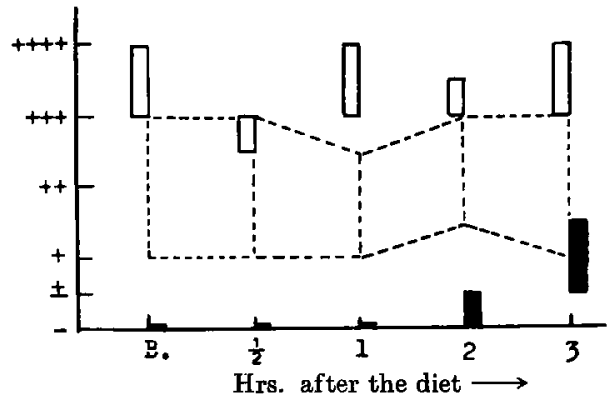

Fig. 14. 2 weeks after vagotomy and hemigastractomy of B.I type (C-group).

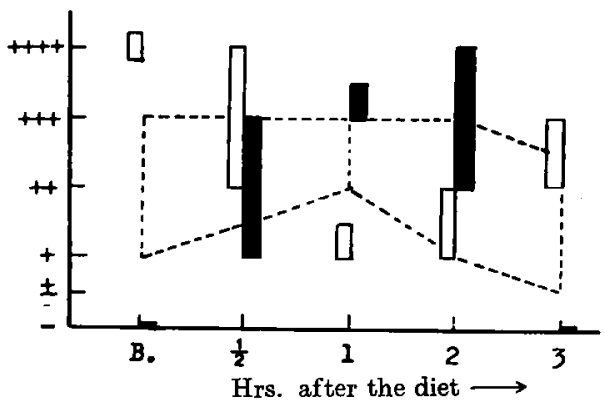

Fig. 16. 3 months after vagotomy and hemigastrectomy of B-I type (C-group).

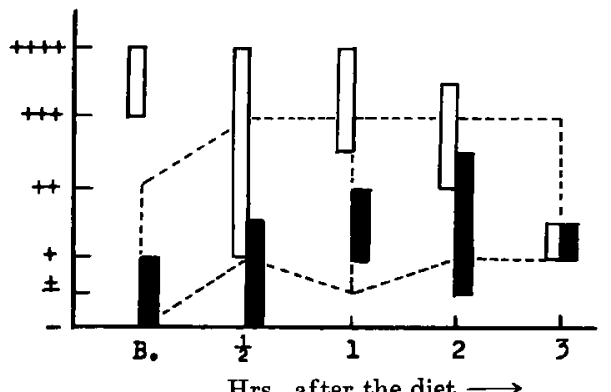

Fig. 18. 2 weeks after vagotomy and hemigastrectomy of B-II type (D-group).

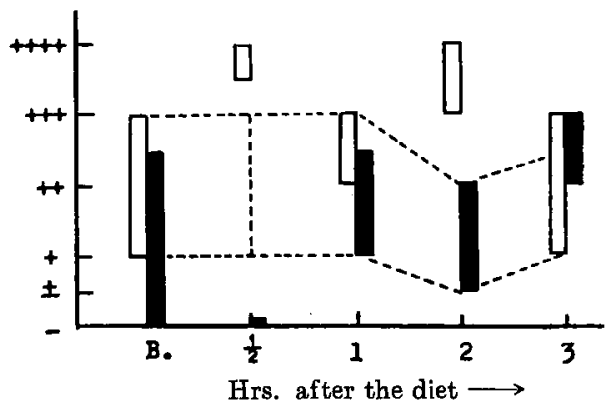

Fig. 20. 3 months after vagotomy and hemigastrectomy of B-II type (D-group). 
action of the sympathetic nerve. In fact, with the frequent findings of these figures in $\mathrm{C}$ and $\mathrm{D}$ groups, the author deems this explanation highly positive.

The cell containing rich secretory granules has few secretory vacuoles. For that reason the author never concludes that the discharge of secretory vacuoles is activated in the cell, because the secretory vacuoles which are prepared in the cell to be discharged may be pushed out easily by the secretory granules produced and accumulated in the cell.

It is noticed in the vagotomy-groups that the secretory activity of the gastric chief cells is not only irregular but their functional figures seem to be often beyond the physiological limit and the secretory activity of the gastric gland does not seem. to be as physiological as in the normal case eventhough the resection of the stomach has been kept at a minimum. However, the question is whether these results have a detrimental effect on the individuals or not, for the general condition of dogs as. regards emaciation, appetite and vomiting after the operation is relatively good in the vagotomy-groups, as shown in Table 2 . Here, we may have the reason why hemigastrectomy with vagotomy is widely employed in the surgical clinics. The author's results, however, will suggest some problems contained in this operation. The mostfavourable results on both the general condition and the secretory activity of the chief cells are found in the group of the subtotal gastrectomy of B-II type (B-group) and this also coincides with the clinical observation of KATSUMI et al. (1965), who. observed the patients for long terms after the gastric operation.

\section{Summary.}

In an attempt to study the effects of the gastric resection on the secretory activity of the gastric gland in the remaining stomach, the author observed the gastricchief cells of operated dogs.

The experimentai dogs were divided into 4 groups for the operation - the subtotal gasterctomy of BLLROTH I type (A-group), the subtotal gastrectomy of BILLROTH II type (B-group), vagotomy and hemigastrectomy of B-I type (C-group), vagotomy and hemigastrectomy of B-II type (D-group). From each group, four small groups were made, determined as follows, 1 week, 2 weeks, 1 month and 3 months. after the operation. Dogs were killed and materials were taken at the periods of 1 . before administration of food (unfed for $24 \mathrm{hrs}$.) and $2.1 / 2,1,2,3 \mathrm{hrs}$. after the diet. The vital fixation by LUNA's liquid and then the fixation by KOLSTER's liquid were employed, and the sections of the stomach were stained by HEIDENHAIN'siron haematoxylin.

The results obtained are summarized as follows:

1. In the group of the subtotal gastrectomy, the secretory activity of the individual chief cell is within the physiological limit, but the activity after the diet is irregular in BILLROTH I type while relatively regular in B-II type. It is so obvious in the group at the long term period after the operation that the different results between B-I and B-II type seem to be due to the difference of stagnation of food in thestomach.

2. The vagotomy induces no inhibition of the discharge of secretory vacuoles in 
the chief cells but brings about the irregular initiation of the secretory activity of the chief cells after the diet. The secretory activity of the chief cells after the vagotomy tends toward the production of the secretory substance in the cells.

3. The liquefaction (externally the vacuolization, preparation for the discharge) of the secretory granules produced in the chief cell is often prolonged or inhibited after vagotomy, and, not seldom, the functional figure of the cell seems to being outside of the physiological limit.

4. The general condition of dogs as regards to emaciation, vomiting and appetite is better in the vagotomy-group than in the others.

5. According to the experimental results of the author, the most favourable operation-results both with regard to the general condition and the secretory activity of the chief cells are found in the group of the subtotal gastrectomy with the gastrojejunostomy (BILLROTH II type).

\section{内容自抄。}

胃十二指腸謴瘍の治㙩法として広く用いられている胃切除が残胃の胃腺分泌機 能に如何なる影響を与えるかを究明せんとして，犬を用いて胃腺主細胞を機能形 態学的に観察した.

実験犬は 1. 胃垔全剔出と Billroth I 法 (胃十二指腸吻合) 群, 2. 胃亜全剔 B-II 法 (胃空腸吻合) 群, 3. 迷走神経切断と胃半切除之 B-I 法群, 4. 迷切胃半切之 B-II 法群の 4 群とし，各群とも術後 1 週，2 週，1 ケ月，3 ケ月の 4 小群に分け， 更に各小群は対照群と共に食䬣負荷により給食前 (24 時間絶食), 給食後 $1 / 2,1$, 2, 3 時間の 5 段階に分けて取材し，Luna 湤による生体固定後胃の小片を Kolster 液にて固定, Heidenhain 鉄へマトキシリン染色標本として検鏡した，得たる結果 は以下の如く要約することが出来る.

1. 胃亜全剔群では, 給食後の胃腺主細胞の機能的動態は個々の細胞について 見ると概ね生理的範疇にあるが, 給食後時間の経過と共に営為される一連の分泌 機能として観察すると, B-I 法例ではかなり乱れが著しく, B-II 法例では比較的 正常に近い，殊に術後長期間を経過した例に於いて然りである．てれは食䭒の胃 内停满に長短の差を生じるためではないかと考えられる.

2. 迷走神経を切断しても主細胞の分泌物放出機能は特に抑制されるとは思え ないが、給食との関係に於ける細胞分泌機能の動態は甚だ不規則となる，また迷 切後の主細胞機能は分泌物新生へ傾いている.

3. 迷走神経切断群では主細胞に 新生された分泌顆粒の液化（外锶上の空胞化, 放出過程への移行）が遅延乃至抑制されたと見做される所見が廈々諗められ，悲 細胞の機能的動態が生理的範疇を出るととが少くないととが知られる.

4. 憔悴, 食欲, 嘔吐などから見た犬の一般状態は迷切胃半切群に於いて良好で ある.

5. 著者の実験成績では胃腺主細胞の分泌機能の動きが正常に近く，また一般 
状態す比較的良好であるのは胃亜全剔 B-II 法群である。

\section{References.}

Amano, T.: Effects of the electric stimulation of the sympathetic centrum on the fine structure of the gland cells. I. On the fundic glands of cats. (Jap.) (Abst.) Kaibo Z. 24 (1949). Beattie, A. D.: Vagotomy and partial pylorectomy. A new procedure for duodenal ulcer. Lancet 258 (1950). - Dragstedt, L. R. and F. M. Owens : Supra-diaphragmatic section of vagus nerves in treatment of duodenal ulcer. Proc. Soc. exper. Biol. Med. 53 (1943). - Edwards. L. W. and J. L. Herring ton : Vagotomy and gastroenterostomy - Vagotomy and coservative gastrectomy. Ann. Surg. 137 (1953). - Herrington, J. L., W. H. Edwards and L. W. Edwards : Reevaluation of the surgical treatment of duodenal ulcer. Surg. 49 (1961). - Farmer, D. A. and R. H. Smithwick : Hemigastrectomy combined with resection of the vagus nerves. New Eng. J. Med. 247 (1952). - Farris, J. M. and G. K. Smith : Role of pyloroplasty in the surgical treatment of gastric ulcer. Ann. Surg. Suppl. 154 (1961). - Katsumi, M. et al. : Evaluation of operation-methods for peptic ulcer by follow-up results. (Jap.) Proc. Kinki surg. Congr. 1965. - Smith, G. K. and J. M. Farris : Vagotomy and pyloroplasty in chronic duodenal ulcer with special reference to technique. Arch. Surg. 78 (1959). - Smith wick, R. H.: Coservative gastric resection combined with vagotomy. Surg. 41 (1957). 